\title{
User-Generated Social Media Events in Tourism
}

\author{
Estela Marine-Roig* (D), Eva Martin-Fuentes (i) and Natalia Daries-Ramon \\ Faculty of Law, Economics and Tourism, University of Lleida (Catalonia), 25001 Lleida, Spain; \\ eva@aegern.udl.cat (E.M.-F.); ndaries@aegern.udl.cat (N.D.-R.) \\ * Correspondence: estela.marine@aegern.udl.cat
}

Received: 16 October 2017; Accepted: 2 December 2017; Published: 5 December 2017

\begin{abstract}
Social media and mobile technologies have revolutionised communication and particular attention has been given to user-generated content (UGC) and the formation of online communities; however, little attention has been given to tourist events entirely generated by users through social media. This paper aims to define and characterise the phenomenon of tourism user-generated events (UGEs) through social media around the user's new empowered role and to assess user-generated social media events' online socialness. It is also our aim to provide a useful mixed-methodology analysis framework for UGEs in relation to social media and to highlight their interest for organisations. The methodological approach includes a quantitative model to store, analyse and compare events' online socialness, which is combined with qualitative, participant observation at the events. This approach is applied to the analysis of three Instagram meetups organised by a specific online community at Catalan ski resorts. The paper's results show the differential characteristic of tourism UGEs: user initiative and empowerment, full organisation and structure, great social media use and UGC production, brand dissemination, attraction capacity, strong online community bond and faithfulness. With UGEs, an event management paradigm shift occurs as organisations are no longer the main initiators and controllers of the event.
\end{abstract}

Keywords: user-generated event; social media; online community; mobile media; user empowerment; convocation; engagement; promotion; Instagram; Catalonia

\section{Introduction}

Something unprecedented and wholly unexpected occurred when, in 2008, an Australian teenager's invitation to a party via MySpace (an early social media platform) went viral. More than 500 people turned up, resulting in damage to the neighbourhood, a street riot and police and helicopters intervening; this event would later inspire the film Project X [1]. Other similar events spontaneously generated by users through social media followed and became increasingly massive, exemplifying the convening power of social media and its potential to go viral [1,2]. In addition, the power of social media to promote and organize collective action and enhance political empowerment has been acknowledged and widely researched [3-5] because "technology-enabled personal networks did not simply function as communication systems but also empowered flexible organizations that allowed rapid action and coordinated adjustments" ([1], p. 8).

Events wholly generated by users and promoted through social media have not only been growing, but have become more formal, organized and specialized in certain subjects [5,6], fostered by the generalized use of mobile devices. Many are eminently touristic and have the capacity to attract people, generate income for tourist businesses and destinations and promote brands. In this respect, social media have not only revolutionized the way we communicate and publicize in travel and tourism [7], but have changed the way we see tourists and their role in the tourism arena [8], from relatively passive agents to empowered agents actively generating content and engaging with one another through mobile devices $[9,10]$. 
Special attention has been given to user-generated content (UGC) online due to its influence on destination and business image formation [11], tourist behaviour [12,13] and its importance for research in tourism and hospitality applications [14]. Thanks to Web 2.0 capabilities and the creation of UGC, online communities related to various topics have flourished. Online communities related to travel and tourism have also been studied in depth $[15,16]$. Kunz et al. [17] found that online travel communities often lead to offline interactions and relationships influenced by individual reputation, online communication behaviour and perceived similarity among members, mediated by trust and sympathy, which may lead to offline encounters and to the creation of events.

However, although the great capacity of social media to organize and publicize events has been acknowledged [18-20], as has as its use by tourism agents, especially destination management organizations (DMOs) to publicize events $[7,10]$, little attention has been given to user-generated events (UGEs) in tourism. These are events with travel and tourism purposes that are created, organized, held and promoted entirely by users (rather than tourism organizations or businesses) through social media, closely bound to UGC and online communities themselves. Moreover, events have mostly been evaluated in relation to their economic impact and not to other socio-cultural outcomes or to their dynamics [21], though, in their exploration of event research, Mair et al. [22] showed that socio-cultural and community impacts were considered the most important sub-topics for future research followed by economic impacts. According to these authors, the media sub-topic (including social media) was ranked in seventeenth position.

Hence, this study aims to define the concept of user-generated social media events, especially on social networks based on images, by identifying their specificities around the empowered role of users, regarding initiative and convocation management, and assessing their convening and promotional capacity through the analysis of their online socialness. Online socialness is defined as social interaction in digitally networked environments, including social media platforms [23]. In this research, events' online socialness is understood as their relationship and interaction with social media, in terms of online brand promotion, UGC production and its influence, engagement and faithfulness of users, the relation with the online community, etc. Event online socialness measures the role and integration of social media in events. Social media based on images are ideal for conducting this study due to their specificities and importance in the tourism domain. In terms of theory, this study aims to contribute to the evaluation model of Brown et al. [21] by emphasizing the need for assessment of online socialness and user centrality in events in the Internet era within larger evaluation systems. This paper also seeks to provide a quantitative framework approach to storing, analysing and comparing events in relation to social media. This framework will be complemented with qualitative participant observation at certain events to deepen the understanding of the events' online socialness and user profiles, empowerment, behaviour, motivations, faithfulness to this type of events and the online community and event management. This mixed-methodological framework will be applied to the study of different Instagram Meetups at Catalan ski resorts. Finally, this paper aims to highlight the advantages of user-generated social media events for tourist organizations as excellent marketing opportunities and pull factors at low or no cost to themselves, and suggest their differentiated denomination (UGE), parallel to that of UGC.

\section{Theoretical Background}

This section first addresses the relationship between tourism events and social media and the tourists' role in them. It then addresses the issue of social media based on photographs in the tourism domain and in relation to events.

\subsection{Tourism Events, Social Media and User Empowerment}

In the context of tourism-related content, events have been studied in relation to a wide range of topics [24]. Mair et al. [22] showed that "events and tourism" was the second most important theme of future research behind "event impacts and outcomes". Events generate tourism demand 
and several studies emphasize their importance for the developing of a destination [25], concluding that the perceived image of a destination and the quality of an event are strongly related to visitor satisfaction [26] and that both the image of the destination and of the event combined influence the decision to travel to that destination $[27,28]$.

Getz [25] points out that there is a considerable amount of literature on business event markets, including affinity-group meetings, and economic impacts. In this vein, Mair et al. [22] highlight this emphasis on the economic dimension in the field of event management and event studies. Although few studies have analysed events from the point of view of tourist promotion or marketing, and although many events are not promoted from a tourist point of view at all [18], it has been concluded that social media are powerful tools to promote, commercialize and shape an event experience [2,29]. Furthermore, social media can help attract tourists to the event's destination [24] through electronic word-of-mouth (eWOM) [30]. Recent studies also indicate that online social networks have increased opportunities to manage the relationship with the attendees to achieve a stronger sense of belonging, which provides added value [20]. Similarly, meeting planners use social media to build credibility and trustworthiness by sharing recommendations and photos of previous events, fostering interest and creating interactive communities among attendees before, during and after the event [6]. Many of these communities revolve around certain brands and may be consumer-created or marketer-created [31,32]. Lee et al. [32] found that the intrinsic altruistic motives of the community and users' social identification motivations are powerful social drivers which encourage users to engage with online brand communities. Online brand communities, and high online socialness with the community, are considered highly beneficial for firms as they are effective tools for influencing sales (the most active members are those who purchase the most), and can retain both novel and experienced customers through customer to customer (C2C) communication [31]. The fundamental idea is that greater online socialness of users leads to greater sales and greater attachment and loyalty to the community, the brand and related events $[6,31,32]$. Today, it is beyond doubt that companies should take advantage of the viral nature of social media to promote, engage users and get feedback before, during and after an event [33] and integrate social media in events as part of their communication strategy [2]. In the particular case of the meeting industry, Wood [34] deems that social media has become a substantial part of the product, enhancing the meeting or even replacing it.

In this respect, with social media, "consumers are beginning in a very real sense to own our brands and participate in their creation ... we need to learn to let go" (Lafley as cited in Hartmann [33], p. 25). In this context, Zanger [2] assesses that, with Web 2.0, a new quality of dialogue communication in events emerges, and suggests the integration of the customer in the process of event marketing, for example, in the design of the event or the choice of its content or location. This author builds a typology of events according to the degree of intensity of connection with social media, from the most to the least integrated: (1) virtual events (held entirely online); (2) hybrid events; and (3) real events, with a complementary use of social media for promotion.

This growing socialness or sociality of events, or their growing relationship with social media, is rooted within a broader trend of network sociality based on individualization and deeply embedded in technology [35]. Users become the centre of this online sociality, exchanging information and socializing by means of social media [36].

Some authors explain that, with social media, the role of users in events has shifted from a passive one to an active one in which they co-produce and co-create the event; they provide ideas, meanings and become brand ambassadors [2,33]. However, although some evaluation models have focused on the collaboration / participation of different stakeholders in events [21], no frameworks have focused on the role of users as full initiative takers or event generators / creators. Furthermore, Hartmann [33] suggests that marketing communication at events should shift its epicentre to the actual participants and their generating of content through social media. However, there is still a long way to go for 
organizations to gain more 'socialness', as a managerial cultural change is necessary to accept that consumers now control the market and events [2,33].

User empowerment has been discussed widely, arriving at the unanimity that community participation is necessary for sustainable development [37]. In the context of our research, events wholly generated by users have emerged and have not only been growing in number, but are becoming more formal, organized and specialized in certain subjects $[5,6]$. Social networks are even proliferating, such as 'Meetup' to organize events by users, with 315,000 monthly meetups [38], many of them eminently touristic. These events cannot be considered co-created, as they are entirely created by users, and thus need new frameworks of understanding which go beyond co-creation theory. These UGEs in tourism have yet to be studied as a distinct social phenomenon, especially linked to online communities and social media, despite their enormous promotional and attraction capacities and significant implications for tourism companies and destinations. Therefore, in this context the analysis of the online socialness and influence of user-generated social media events, and their particularities should be studied.

As argued in this section, social media are key to this process of user empowerment and event creation, and within social media, pictures are a very significant UGC element, especially in the tourism field, with increasing numbers of travellers sharing pictures online $[39,40]$.

\subsection{Social Media Based on Photographs}

Nowadays, social media dominate the digital user environment. In recent years, with the proliferation of the use of smartphones and other mobile devices with built-in cameras, new types of social media based on images/photographs have become increasingly important due to their usefulness and ease with which users can share content. These new social media attract a younger audience with a high return rate. In these media, each image has attached identification metadata through which users can search, navigate and order according to their interests and priorities [41], and it can be accessed by millions of users worldwide.

The qualities of pictures to communicate concepts and feelings are very relevant. As a famous saying has it, "a picture is worth a thousand words", or as Abbott et al. [42] put it: "an Instagram is worth a thousand words". This is why, not surprisingly, social media communication is largely based on images. In tourism, there is a primacy of visual imagery in the promotion and advertising of destinations and attractions, and the subsequent 'capture' of such images by tourists through taking photographs becomes crucial for tourist image formation and reproduction [43]. In this respect, online visual images retain more impact and are far more engaging than text alone [42] and their online sharing may reinforce a destination's or brand's 'lovemark' of and provoke deeper loyalty [44], making these images powerful tools for tourism marketing. Indeed, a positive relationship has been found between the photographic behaviour of tourists (such as sharing) and their happiness [45]. Moreover, in a few words the text which accompanies images in posts reflects emotional values that lead to affective bonding and attitudes toward a place, a person or a product $[42,44,46]$.

The inseparable connection between modern recreational travel and photography [43] makes photograph-based social media especially popular in relation to travel and tourism. Lo et al. [39] revealed that most pleasure travellers take photographs and almost half of them posted their photographs online. Social network sites, instant messaging, online photo albums and personal blogs were the most popular media used. Photographs taken by tourists and posted on media-sharing websites affect perception of a place as a travel destination by those who view such images [12] and can have amplifying effects in viral forms, provoking favourable attitudes toward the destination/brand [44]. As Markwell [43] explains, photographs reveal not only the experience but who took them, and the fantasy of the perfect holiday is reinforced by the selective sampling of the photographer. Moreover, tourists who post pictures on social media are especially interesting for companies and destinations as they are more likely to purchase souvenirs as gifts and products 
as evidence of travel than non-picture posters [46], and may generate economic impacts in the areas they visit.

In this context, the study of social media based on photographs becomes crucial for the understanding of tourism UGES, as they are key to developing tourism-related online communities and to understanding users' role and behaviour, and may be important in determining an event's online socialness in the field of tourism.

\section{Materials and Methods}

Event research methodologies have mainly focused on assessing economic impact and there is a need for methodological advancement in other fields evaluating socio-cultural aspects and event dynamics [21]. Besides this, in tourism and event research, the combination of qualitative and quantitative techniques is used to achieve better results and understandings [21,47]. Therefore, this study adopts a mixed methodology, including positivist and interpretive approaches [21] to analyse and characterize the socio-cultural phenomenon of UGEs, including the proposal of a quantitative analysis framework to store, analyse and compare an event in relation to its online socialness, as well as the people actively participating in the event as social media users, along with a qualitative approach to complement the quantitative analysis based on participant observation in the events to gain deeper understandings of the events' online socialness and users' role of empowerment. This method is applied to a case study of three Instagram meetups at Catalan ski resorts organized by an online community.

\subsection{Measures, Metrics and Methods to Assess Social Media Contributions}

From a quantitative perspective, the event's online socialness will be mainly measured through the assessment of users' social media contributions. Several authors propose the indicators, metrics and methods to measure the impact of social media contributions. Additionally, several online portals assess the online influence of social media users.

From a practical point of view, Kaushik [48] proposes the first three measures as calculated through metrics available in each social media: conversation, amplification, applause, and the fourth, which is quantified through specialized portals: economic value measuring bottom-line business impact. From a marketing perspective, Zarrella [49] proposes a set of metrics to measure the business objectives (exposure, engagement, influence, impact, and advocacy). In this line, Pan et al. [50] propose a framework based on a multidimensional network composed of nodes (actors and memes) and the connections between them to determine marketing-oriented measurements: social media presence; social media involvement; awareness, reach, lead generation, and brand liking; response rate; and recommendations, virality, and audience engagement. Concerning the notion of a performance measurement system (PMS), Agostino et al. [51] display indicators, measures and methods for data collection and data analysis to quantify the contribution generated by social media activities.

Regarding users, influence is a very significant measure. Influence is the ability to drive/inspire action (Klout.com, Kred.com). These portals score the quantity, quality, and frequency of reactions that generate users' social media contributions, based on several metrics such as retweets, replies, mentions, shares, likes, comments, and event invitations. Thus, a user's influence increases when others interact with their shared content, but also their generosity in engaging with others and helping spread their message (outreach measure). According to Peters et al. [52], such highly engaged fans are crucial in building sustained and authentic reach in social media (p. 292).

Previous empirical studies have determined capacity to disseminate tourist image or brand and level of user engagement with UGC posts through the analysis of interactivity and reactions (likes, comments and shares) generated in social media [53,54]. Specifically, user engagement with Instagram posts has been analysed through followers, comments and likes [42,55]. Moreover, the 'buzz' or dissemination of events through social media has been analysed through posts uploaded, such as 
photographs and videos, and the number of views they have had; the role of 'influencers' is especially emphasized [33].

\subsection{Object-Oriented Framework}

In this context, from a quantitative perspective, to store, analyse and compare UGEs' online socialness through social media, we propose a model which can be used and adapted to any type of event and/or social media platform. This model has at its basis the identification and analysis of the UGC posts produced in relation to the event, to obtain information about participants, promotion and the event itself.

Within the scope of the case study, the methods seen in the previous section to collect (ad hoc social media data download) and analyse the data (statistical analysis) do not set out how to store and process information. With this purpose, an object-oriented framework is proposed through a standard language, the unified modelling language (UML). UML is a general-purpose graphical language for visualizing, specifying, constructing, and documenting the artefacts of a software system. As the de facto standard modelling language, the UML facilitates communication and reduces confusion among project stakeholders [56]. From a UML class diagram source code can be generated for an application in some object-oriented programming languages. The objects created are reusable and extensible. In the field of tourism, the UML has had little use, except for Hopken [57], who proposed it to design a framework for interoperability among heterogeneous electronic tourism markets.

Figure 1 represents a simplified UML diagram to store and analyse an event that is represented by four objects (Event, Firm/DMO, User and Post) and the relationships between them. Boxes have three sections: class name, attributes and methods. The Event class is associated to the User class and with the Firm/DMO class with a cardinality $\left(1,{ }^{*}\right)$. That is to say, an event is associated with an indefinite number of users and firms and, therefore, we can know in every moment how many users and companies participate. User class is associated with an indefinite number of posts (photographs). The diagram shows the basic attributes gathered per class: time, likes and comments per post; profile (gender, for individuals, and type of organization for other users) and followers per user; event name, hashtag, location, date and influx; and name, branch and role per firm/DMO. Moreover, an event has five basic methods which go through the list of users and through the photograph list of each user:

- photos(): This method calculates the total number of pictures that have been submitted with the corresponding hashtags.

- dissemination(): This method calculates the quantity of potential Instagrammers who have received the pictures in first instance, by adding up the followers of users.

- interactivity(): This method calculates the quantity of reactions (likes and comments) that users' posts had.

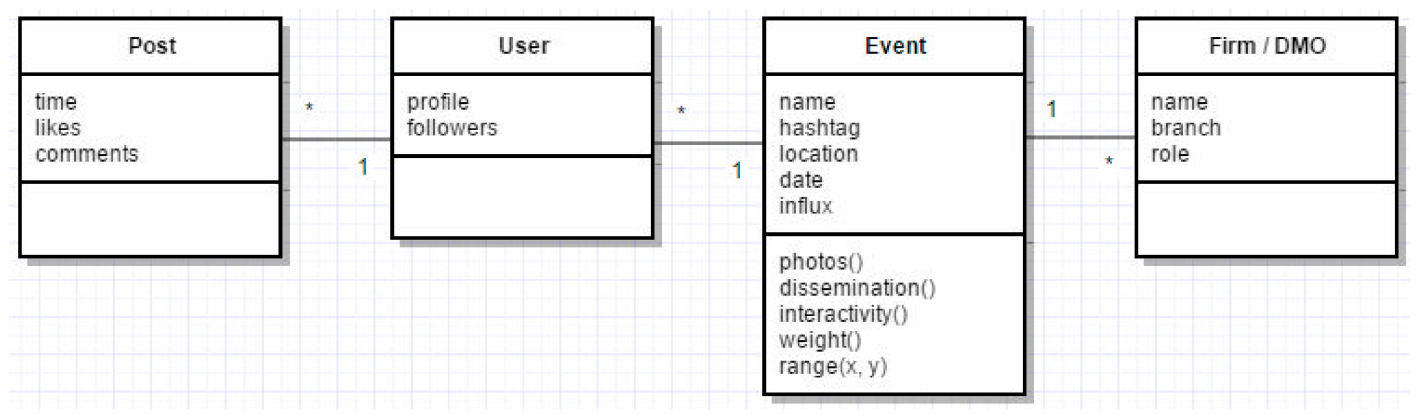

Figure 1. Simplified object-oriented UML diagram to store and process UGEs. Cardinality 1: one entity; cardinality *: zero, one or many entities.

To be able to compare different events, the Event class counts on auxiliary methods: 
- weight(): This method calculates the growth in percentage that the number of user participants represents over the average visitors (influx attribute) in the area and season when there is no special event. This enables the comparison of the impact of events in different areas and/or dates.

- $\quad$ range $(x, y)$ : This is a parameterized method that enables the calculation of different types of ranges such as posts per user (to detect the most active users), followers per user (to detect their role as 'influencers'), likes per post and comments per post (to detect the most engaging posts). Ranges are calculated in percentage to compare events with different numbers of participants.

Finally the Firm/DMO class and the association with the Event class enables knowing the quantity, name, branch (industry, services, management...) and the role they play in relation to the event (support, sponsoring...).

With this model, the different attributes and methods can be aggregated and compared within an event or across different events. Thus, the number of repeat and new participants at different similar events should be identified to detect faithfulness.

\subsection{Participant Observation}

Participant observation in the events will study different aspects of the events' online socialness and the new central empowered role of users as initiative takers, managers and event creators. In this respect, participant observation is a recognized, though underused, method for event analysis which enables the collection of information on the development of the event's management strategies, social interactions and behaviour of participants, thus providing meaningful, event-specific data [58]. Participant observation is also a recognized method in tourism, with special utility for tourism research in areas such as tourist satisfaction / dissatisfaction, behaviour and management questions [59] as well as in the observation of tourist groups or events [58]. Specifically, participant observation has been used to analyse tourist behaviour in relation to photography [43,45] and online photo-sharing [60]. This technique is considered as being a microethnography [60], which analyses social and cultural interactions in an organized context or particular situation.

Participant observation is especially appropriate for exploratory and descriptive studies [61], providing observations to help the researcher better understand the context and phenomenon of study [62]. To gain a better understanding of UGEs (Instagram meetups), participant observation aims at observing the new empowered role of users as event creators, managers and participants, as well as tourists' behaviours and interactions around photography and social media to gain insight into their opinions and motivations [63]. The specific application of participant observation is explained in the case study section.

\subsection{Case Study: Instagram Meetups}

Instagram is an image-based social network, created as a free mobile app and focused especially to be used with smartphones, and has become most popular in recent years, with more than 600 million users, 300 million daily users, and 40 billion stored pictures (the biggest phototheque on Earth). As regards demography, $68 \%$ of Instagrammers are females, $28 \%$ of Internet users between the ages of 18 and 29 , and $4 \%$ between 30 and 49 use Instagram [64]. Instagram has become a reference medium for people to share creative experiences of their lives instantly, and goes far deeper into emotions than do other social media. The flows of images on Instagram are live and ephemeral, 'instantaneous', receiving most attention within the first few hours of being posted [42,55].

Instagram can be effectively integrated in the publicity of brands or products thanks to its everyday character which humanizes brands and allows users to participate in their daily environments and processes, in a less institutional way, generating effect and engagement [55]. Analysing Instagram helps gain insights into social, cultural and environmental issues related to people's activities through their mobile camera lenses [65]. 
Especially remarkable are Instagram communities concerning certain topics [66], many of which revolve around tourist destinations by displaying pictures of them using specific hashtags to tag images of attractions, monuments or places at the destination (such as \#igers_place or \#ig_place). In this respect, through Instagram, several social phenomena are generated: photography competitions, courses, insta-talks, insta-walks, prize draws, and Instagram meetups or events, many entirely generated and run by users.

An InstaMeet is a group of Instagrammers who meet up to take photos and videos together forthwith, mainly through their smartphones and mobile devices. An InstaMeet can take place anywhere and be any size. They provide an excellent opportunity to share tips and tricks with other community members, and an excuse to get out and explore someplace new. For instance, the Worldwide InstaMeet 15, Tirana (Albania), 25-26 March 2017 (\#WWIM15) has collected more than 30,000 posts. Thus, the Instagram team allows users to organize InstaMeets and gives the following advice: "Think of a creative, visual place and spread the word for others to join. Post a photo or video that announces the time and location, and use Instagram Stories to get people excited. And don't forget to tell us about it." [67].

Attendance at the meetings ranges from tens to tens of thousands of Instagrammers, but those organized by private users hover around the hundred mark. The selected case studies can be considered representative of InstaMeets, because they were attended by hundreds of users and are comparable since they were held during the same season at similar holiday resorts in the same touristic region. The online community organizing the meetings (DescobreixCatalunya/DiscoverCatalonia) was created in October 2012 by a group of friends interested in travel and tourism and promoting Catalonia as a tourist destination, especially for the local public with the profile @DescobreixCatalunya. This community holds the second-largest account on Instagram (in number of followers) about tourism in Catalonia, after the institutional account of Catalunya Experience, and is the largest community managed by users. This Instagram community organized three different 'Instagram meetups' at three ski resorts in the Catalan Pyrenees: La Molina (LM), Port Ainé (PA) and Vall de Núria (VN) during the months of January and February 2015 (Table 1). Iin addition to skiing, all offered plenty of leisure activities, such as adventure sports, nature trips, snowshoeing trips, snow parks, etc. The Instagram meetups were described as leisure and discovery events, linked with snow and winter activities directed toward the public in general, especially families.

Table 1. Instagram meetups in the Catalan Pyrenees.

\begin{tabular}{cccc}
\hline & La Molina (LM) & Port Ainé (PA) & Vall de Núria (VN) \\
\hline Ski area/slopes & $61 \mathrm{~km} / 53$ & $30 \mathrm{~km} / 25$ & $7 \mathrm{~km} / 11$ \\
\hline Winter season (14/15) Visitors & 265,798 & 105,296 & 45,944 \\
\hline Influx (avg. daily visitors) & 2950 & 1170 & 510 \\
\hline Day of the event & $18 / 01 / 2015$ & $22 / 02 / 2015$ & $08 / 03 / 2015$ \\
\hline Participant places & 200 places & 450 places & 500 places \\
\hline Specific event hashtags & $\begin{array}{c}\text { \#descobreixlamolina } \\
\text { \#clicalamolina }\end{array}$ & $\begin{array}{c}\text { \#descobreixportaine } \\
\text { \#clicaportaine }\end{array}$ & $\begin{array}{c}\text { \#descobreixvalldenuria } \\
\text { \#clicavalldenuria }\end{array}$ \\
\hline Instagram account & @lamolinaski & @port_aine & @valldenuria \\
\hline
\end{tabular}

This community had previously arranged with the ski resorts to give discounts to the participants in the event for ski passes and equipment rental. The events also had an official sponsor: Moritz, Barcelona, Spain (a Catalan brewer). Participants had to be Instagrammers and follow the ski resort's Instagram account to be eligible for the discounts and to participate in the photography competition. Registrations for the events were limited to members of the Instagram community, and one accompanying person per Instagrammer. The community members had a period of about 10 days to register (themselves and their companions) until there were no places left. Remarkably, on all three occasions, places were filled long before the event. 
Participants, usually active Instagram users, were motivated to post pictures on Instagram with the corresponding hashtags (see Table 1) and something related to the sponsor of the event (Moritz) on the day of the event or the days immediately after because they would participate in a competition. To enter the contest, photographs had to be: geotagged, taken on the day of the event, have the hashtags of the event, be posted in a public profile and incorporate the sponsor of the event. There were five prizes for the best photographs (e.g., an adventure pack for two or a spa pack) and two special prizes for the most original 'Moritz photographs'.

Hence, for quantitative analysis of online socialness, all photographs with the hashtags proposed by the community @DescobreixCatalunya used to label the pictures taken during the events, posted on the day of the event and two following days, were gathered and analysed. This period of photograph analysis is congruent with the 'instant' or ephemeral nature of Instagram pictures' impact [55].

The proposed quantitative model was applied to the three events of the case study, and the different attributes for Posts, Users, the Event and the related Firm/DMO were gathered and the methods applied.

For the qualitative analysis of UGEs and of the new empowered role of users as their creators as well as their online socialness, through participant observation, guiding principles as set out by Bowen [59] were applied: The research problem was approached from the perspective of the tourist (insider), the events were not created or manipulated by the researcher and the setting was natural. The researcher was constantly aware of the need to forge a balance between a passive and a proactive presence. During the participant observation, DeWalt's [62] suggestions were followed: actively observe, attending to details; look at the interactions, counting persons or incidents; listen carefully to conversations and nonverbal expressions to seek out new insights; and keep a running observation record.

In this case, observation was performed by a team of two researchers in each of the three settings (LM, PA and VN), between 7:00 a.m. and 4:30 p.m. The events had a predetermined size limit with regard to user numbers (see Table 1). According to Bowen's [59] basic typology of field roles, the researchers were full participants, registered for the events. The observed group consisted of event participants in their different activities and researchers joined groups of Instagrammers for meals or breaks. The methods for gathering data were mainly field notes (taken during breaks, after activities and at the end of the day) and photographs. Field notes were organized into themes: participants' characteristics (demographics), users' initiative and role of empowerment, event management, behaviour and relationship to photography and social media, basic travel motivators [63] and faithfulness to the online community. These themes were chosen to analyse both the online socialness of the events and users' role of empowerment and to gain a general understanding of the events in relation to the online community and users' behaviour in them.

\section{Results}

This section first presents the quantitative results obtained through the application of the proposed analysis model for the analysis of the events' online socialness. The section then provides the qualitative results of participant observation which focus on the relationship of users with social media and their new role of empowerment.

\subsection{Participants (Users) Posting Pictures on Instagram and Dissemination}

The first aspect we can observe is that, on the day of and two days after the events, around 100 different users posted photographs for each event. These users had an average of around 2500 followers and posted about four photographs each. Remarkably, the number of users, followers and average posts was extremely similar and proportional across the three events (Table 2), which may indicate the impact of similar future events. Using the Dissemination() calculation, we see that these users potentially ranged in total from 235,811 followers, in the case of PA, to 291,434, in the case of LM. This is a maximum threshold of dissemination of about a quarter million followers at each event. 
Table 2. Information about Instagram users who posted photographs.

\begin{tabular}{ccccccc}
\hline & $\begin{array}{c}\text { Different Users } \\
\text { Posting Photos }\end{array}$ & $\begin{array}{c}\text { Total Followers } \\
\text { of Users }\end{array}$ & $\begin{array}{c}\text { Avg. Followers } \\
\text { Per User }\end{array}$ & Max. Followers & $\begin{array}{c}\text { Average Posts } \\
\text { Per User }\end{array}$ & $\begin{array}{c}\text { Max. Number } \\
\text { of Posts }\end{array}$ \\
\hline LM & 104 & 291,434 & 2802.25 & 40,200 & 4.67 & 23 \\
PA & 91 & 236,811 & 2602.32 & 38,900 & 4.05 & 34 \\
VN & 110 & 256,562 & 2332.38 & 39,780 & 4.00 & 20 \\
\hline
\end{tabular}

Using the range (x,y) method, with regard to followers per user (Figure 2), in all cases most users had between 200 and 499 followers, which is a significant number of people who may see each of the posts. The next-largest cluster pertained to PA and VN, where users with very few followers (1-49) were counted, indicating that a significant segment of users will not have a very large dissemination of their images and probably created an Instagram account specifically to participate in the event, showing great interest this way. Most importantly, about $25 \%$ of users are highly influential, with more than 1000 followers, and generate high image dissemination and interaction. This target segment is especially interesting for marketing purposes for tourist destinations and businesses. The most influential users had about 40,000 followers each. The community @DescobreixCatalunya also posted photographs and had more than 34,000 followers during the events.

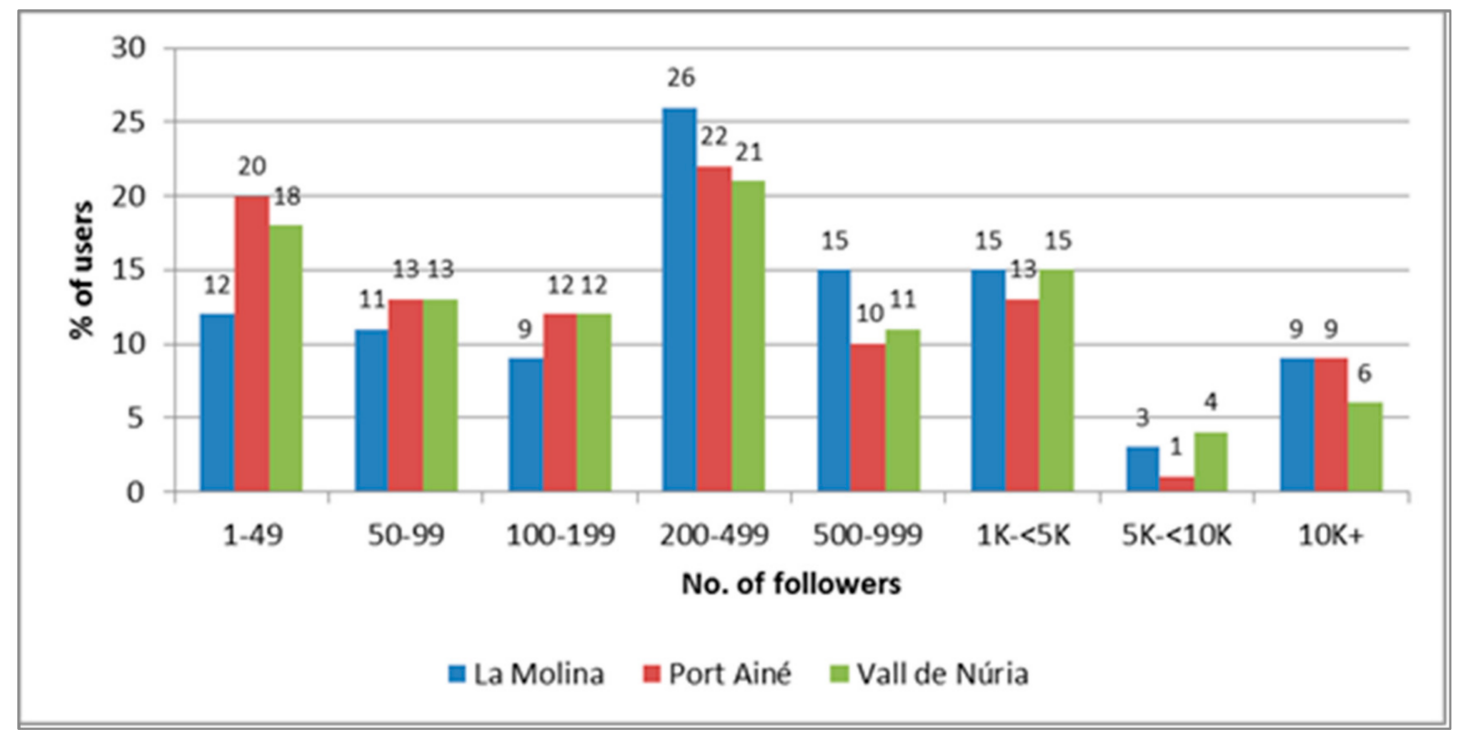

Figure 2. Followers per user.

Using the range ( $x, y)$ method, posts per user were identified (Figure 3): In general, we can see that most users posted only one photograph, followed by users who posted 3-4 pictures or 5-9 pictures. Rarely do users (about 10\%) post more than ten pictures. This can be explained by the subculture of Instagram users who tend to post their 'picoftheday' and select only the very best pictures to post.

Instagram user participants who posted pictures related to the events were mostly individuals, more female than male (Figure 4). Some users could not be identified (unknown) but most were individuals. Then came communities and businesses that, despite being few in comparison to individuals, had especially high numbers of followers and interactions with their posts, and participated mixed with other event participants. All three ski resort profiles (@lamolinaski, @port_aine, @valldenuria) actively participated in the event by posting pictures. 


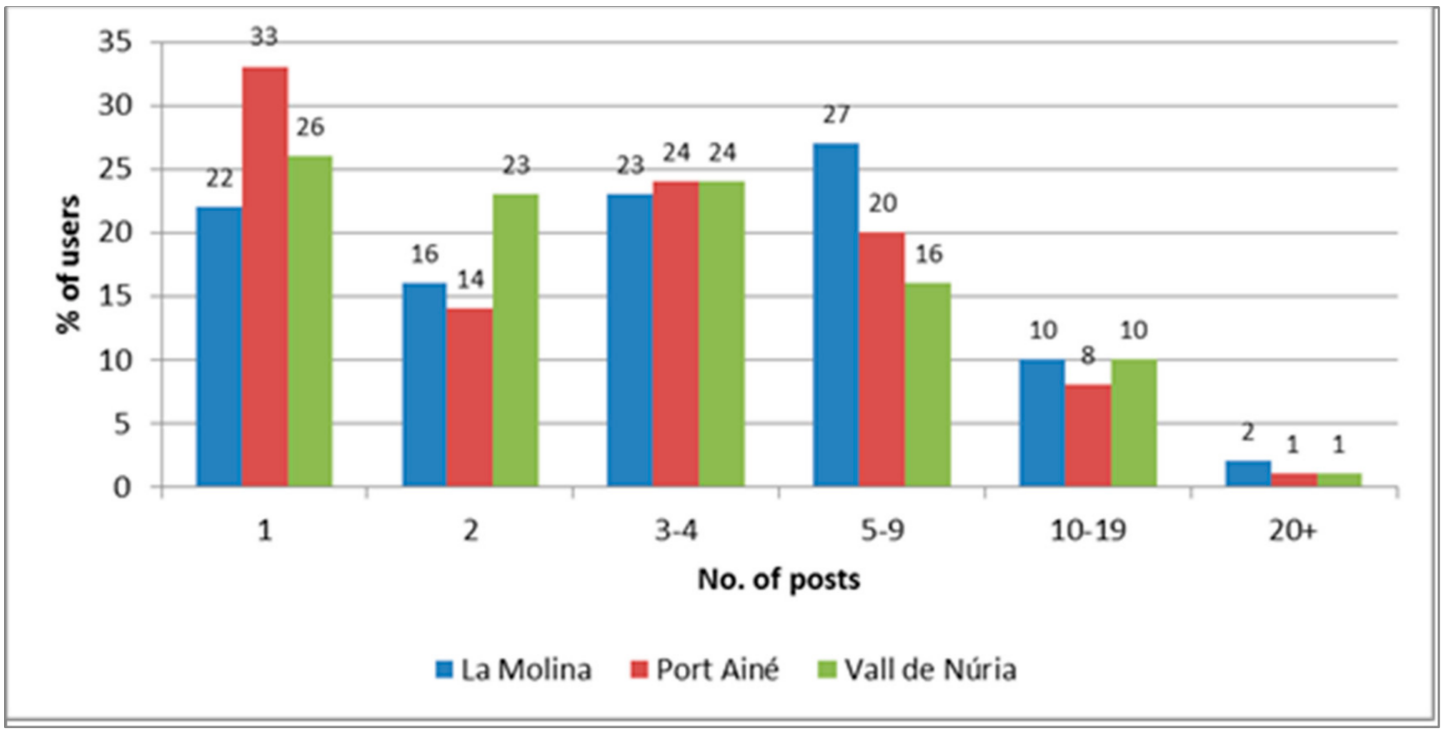

Figure 3. Posts per user.

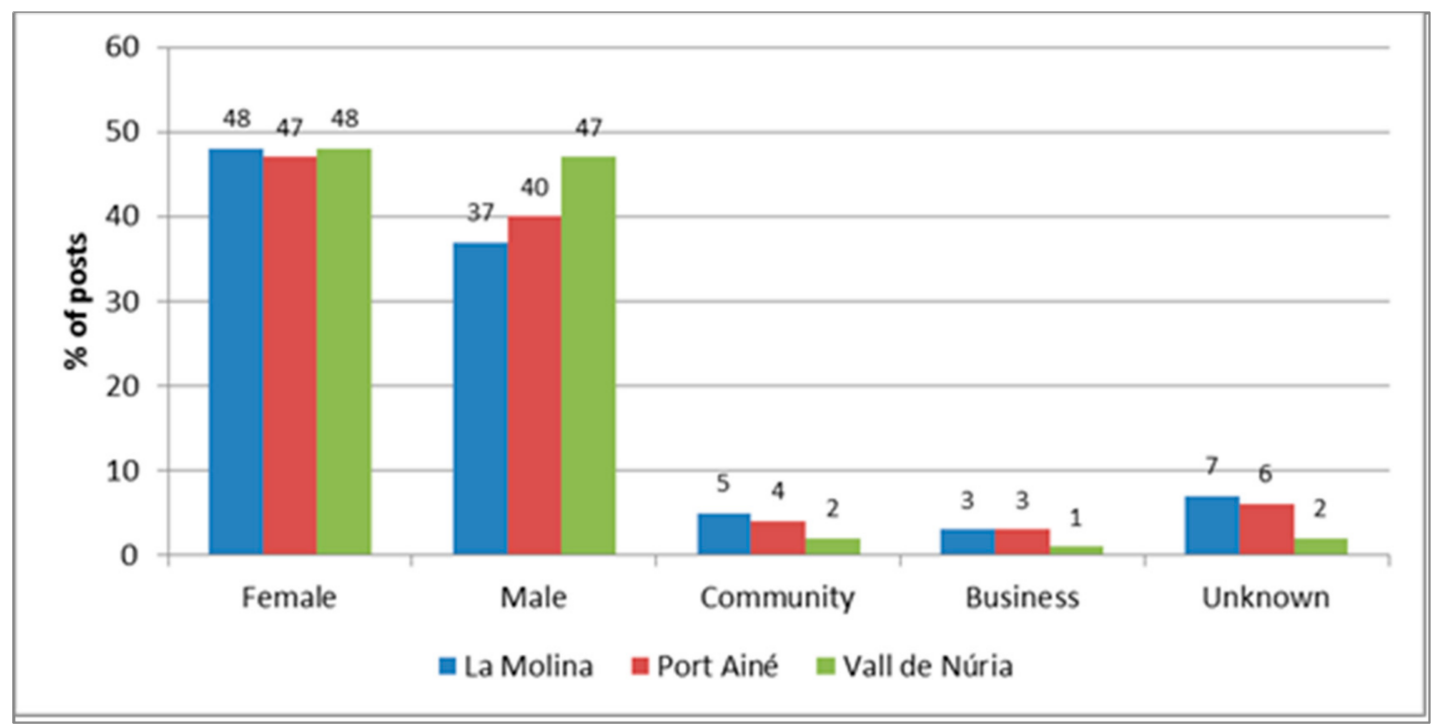

Figure 4. User profile.

Regarding user faithfulness to these events, in adding up the three consecutive events, 238 different Instagram users participated and posted pictures and of these, remarkably, 21.8\% of users attended more than one event, and about $5 \%$ attended all three events (Table 3 ). This indicates a high degree of faithfulness to the Instagram community and a particular type of event, while at the same time indicating the events have the capacity to attract new people. More than $20 \%$ of repeaters is very significant as the events were held on different weekends and in relatively distant locations, indicating generally positive satisfaction with the experience. The $4.6 \%$ of users who attended all three events mostly correspond with members of the @DescobreixCatalunya community, who are very influential as being in the top segments of numbers of followers (all of them had more than 2000 followers). About $80 \%$ of people attended only one event. 
Table 3. Repeat participants to the events.

\begin{tabular}{ccccccccc}
\hline & LM & PA & VN & LM + PA & PA + VN & LM + VN & All 3 & SUM \\
\hline No. of users & 65 & 53 & 68 & 11 & 12 & 18 & 11 & 238 \\
Percent & 27.3 & 22.3 & 28.6 & 4.6 & 5.0 & 7.6 & 4.6 & 100 \\
\hline
\end{tabular}

\subsection{Posts and Interactivity through Instagram}

With regard to photograph posts that had both hashtags related to each of the events (Photo() method), each event generated from 360 to 486 photographs (Table 4), with about 48,000 to 85,000 likes (Interactivity() method). Curiously, in VN, a single-day event generated a greater number of likes by users than the number of yearly winter visitors to the ski resort. Each event generated from 3700 to more than 7700 comments (Interactivity() method). This shows massive interactivity with posts, where multiple users, including the participants at the event, actively and purposefully liked or commented on the photographs. Moreover, each post had about 150 likes and 12 comments, and the most popular had more than 1800 likes or 130 comments alone.

Table 4. Information by photographs posted related to the events.

\begin{tabular}{cccccccc}
\hline & $\begin{array}{c}\text { Total } \\
\text { Photos }\end{array}$ & $\begin{array}{c}\text { Total } \\
\text { Likes }\end{array}$ & $\begin{array}{c}\text { Avg. } \\
\text { Likes Per } \\
\text { Photo }\end{array}$ & $\begin{array}{c}\text { Max. } \\
\text { Likes }\end{array}$ & $\begin{array}{c}\text { Total } \\
\text { Comments }\end{array}$ & $\begin{array}{c}\text { Avg. } \\
\text { Comments } \\
\text { Per Photo }\end{array}$ & $\begin{array}{c}\text { Max. } \\
\text { Comments }\end{array}$ \\
\hline LM & 486 & 85,707 & 176.35 & 1453 & 7763 & 15.97 & 136 \\
PA & 360 & 47,989 & 133.30 & 1565 & 3694 & 10.23 & 130 \\
VN & 444 & 60,558 & 136.39 & 1835 & 4572 & 10.30 & 97 \\
\hline
\end{tabular}

Using the Range ( $x, y)$ method to identify likes and comments per post (Figure 5), we see that, for two of the events (PA and VN), about $50 \%$ of posts had less than 50 likes. In the case of LM, however, this figure is only $28 \%$. Usually, there are fewer and fewer posts as likes increase. However, it is not negligible that about $15-20 \%$ of posts had between 100 and 199 likes, and that $17 \%$ of posts, in the case of LM, had between 200 and 499 likes. Remarkably, about 10\% of posts had more than 500 likes, which entails very high interactivity. The two latest events (PA and VN) seemed to behave more similarly than the first (LM) in terms of likes.

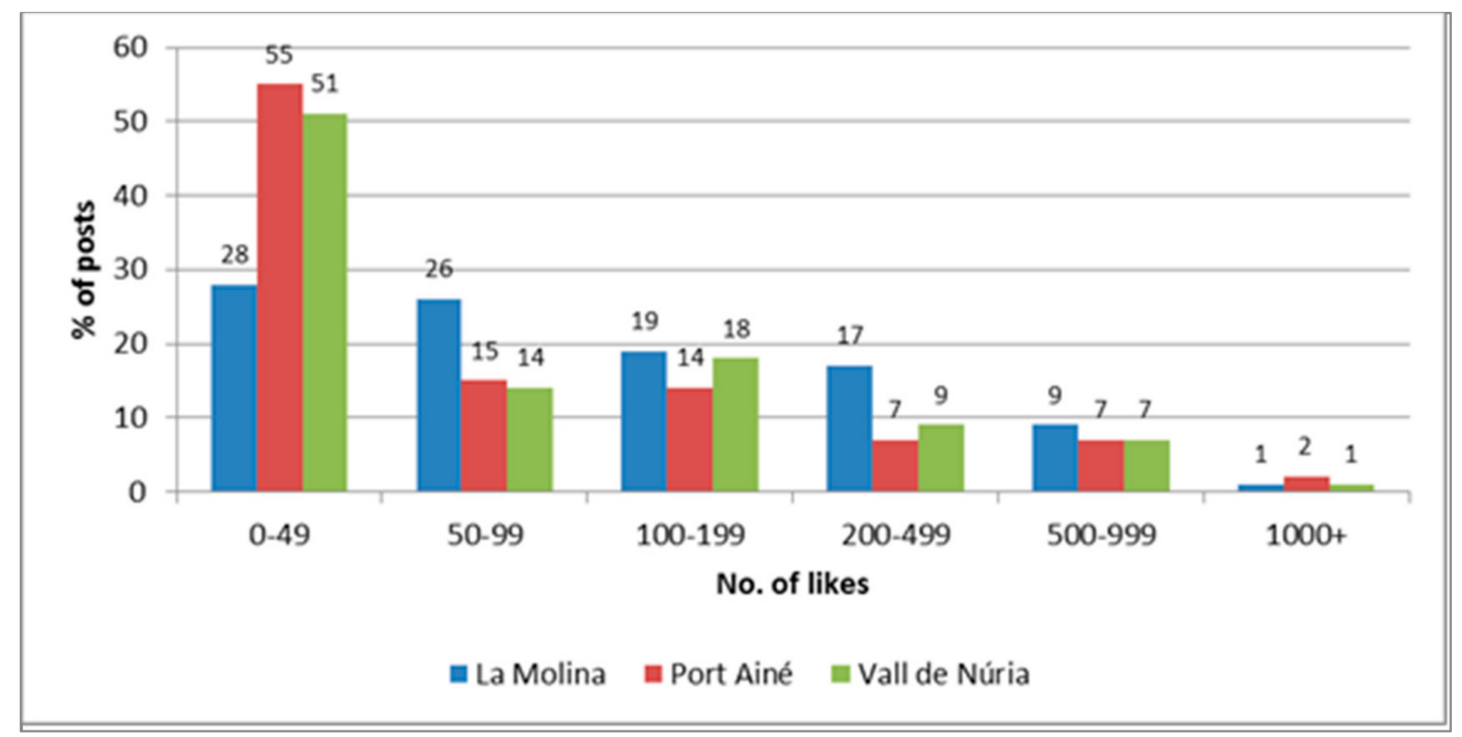

Figure 5. Range of likes per post. 
Comments were less frequent at the last event (VN) (Figure 6). At both PA and VN, the most frequent case is that pictures had one or no comments, while in the case of LM, most pictures (one in three) had between 10 and 19 comments, indicating higher interactivity. Again, some specific pictures ranked highest (surpassing 100 comments), usually corresponding to the users with the greatest number of followers and generating true conversations around the event or picture.

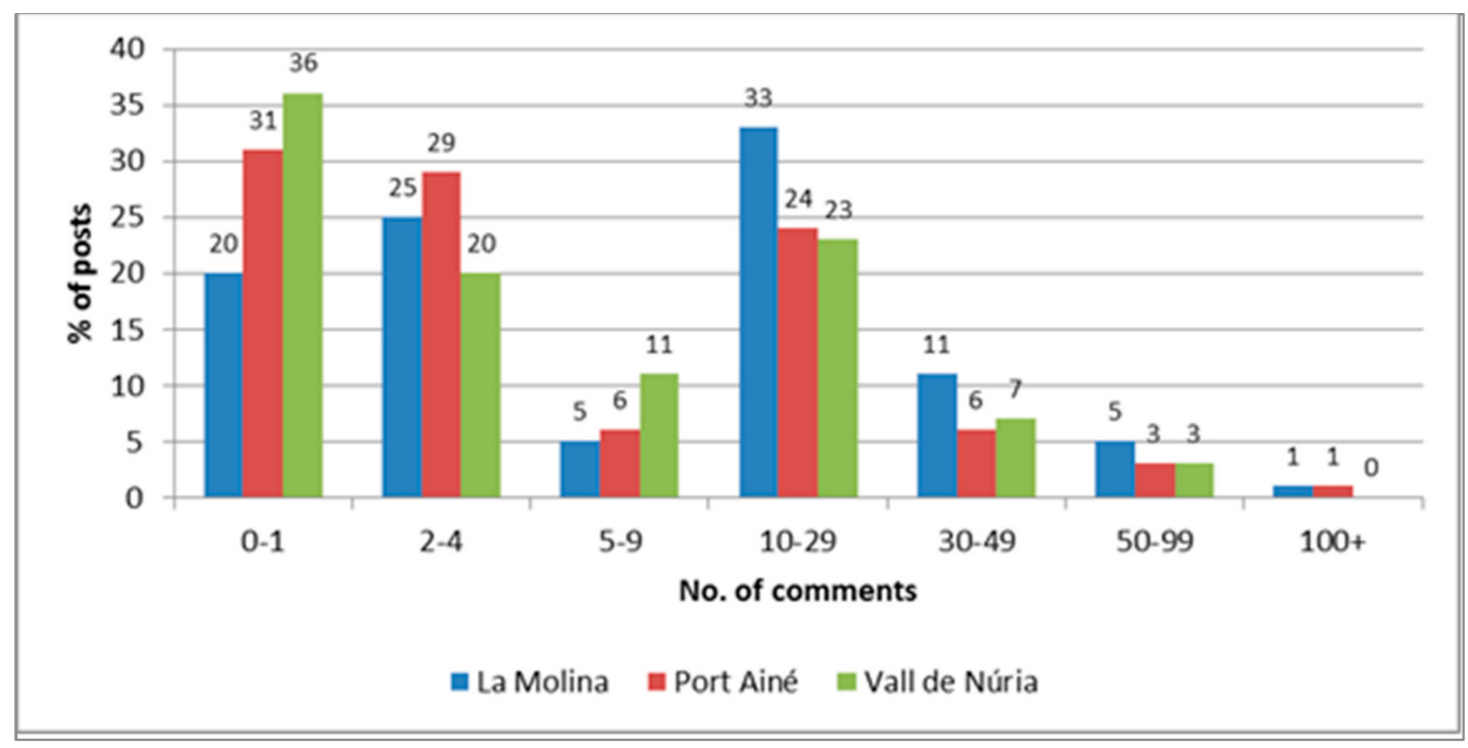

Figure 6. Range of comments per post.

Along overall lines, we can assert that the first event (LM) behaved quite differently from the second (PA) and third (VN) events. The first event had a greater total social media impact than the others because the participants had more followers and posted more pictures in general and on average, and registered a considerably higher number of likes and comments. Moreover, the top segments of the graphs (most influential) were higher in the case of LM. This could be explained by the fact that the first event enjoyed the novelty factor to attract more interest and interactions. Also, probably at first, only the most engaged social media users with the Instagram community and that have high numbers of followers knew about and participated in it, whilst after the success and dissemination of the first event, the remaining events reached a broader public that might not be so close to the online community. However, in relative terms, the impact of participant numbers for the ski stations, applying the weight() method, was very different: For LM, the event participants only represent an increment of $6.7 \%$ on their average daily visitors. Conversely for PA, this represents an increase of $38.5 \%$ in daily visitors and of almost $100 \%$ for VN. Hence, we see the special interest UGEs may have for small ski resorts (destinations or companies) and their potential economic impact.

\subsection{Participant Observation}

Characteristics of the participants: Most participants were 30 to 40 years old (this can be explained because the InstaMeets were advertised as family activities), although many participants in their twenties were seen, and in general had a medium-high education level and medium purchasing power. Most did not work in jobs related to photography; some mentioned being teachers, secretaries, engineers, business people, etc. Some participants, about 1 in 4 , came with their children. From what we could see and hear, because of the language spoken, the vast majority of participants were Catalan, with large numbers from Barcelona.

User initiative/empowerment: Most participants we interviewed considered the events as their own, even if they had not organized them. They saw the event as something created by peers for 
peers. A mother of two reported "it is very nice that people take such initiatives [UGE] to promote their country and identity [ ... ] better than governments! ... I feel proud". Participants' attitude was always helpful both of organizers and simple participants. As participants felt the event was their own, whenever we asked or had doubts they actively tried to help, explain or even take us to the starting point of the activity, etc.

Management: When we arrived in the morning participants were gathered at a meeting point. There, the event organizers gave participants a badge so they could identify one another. The organizers, in addition wore an extra blue arm band, so that people could know who to ask. Information was given about the different activities and times, but people were also given complete freedom to join or leave activities at any time. The organizers gave great importance to joint community activities and gatherings such as the activity of having hot chocolate and cake together.

Behaviour and relationship to photography and mobile social media: During the events, while some participants used cameras, most of them used smartphones to take multiple pictures and upload them to social media, and to participate in the event competition. Interestingly, because the Instagram photography competition implied that the sponsor should be present in the photographs, staging the pictures was highly accentuated, with tourists handling Moritz bottles or bottle-tops to set them in the frame before taking a 'perfect' picture.

Tourist photography is seen as an acquisitive or even predatory act [43]. In this respect, early in the morning of the events, many participants were taking pictures of the best views of the site, trying to be the first ones to post images of these places on Instagram with the event hashtags. Many users acted somewhat surreptitiously, trying to find a unique view or spot to take pictures, but some, especially in group activities, adopted an imitative attitude and copied others' ideas for pictures by taking similar shots of the same things. In all events, there was a lot of photography talk and people asked for advice from their friends and family, very similarly to what Markwell [43] identified.

Travel motivators: Participants were observed to be motivated by both sport/exercise and relaxing entertainment. Although most people participated in skiing and other sports activities, some remained in the cafeterias or in leisure areas and many stopped from time to time for a drink or even to play cards with friends or family. From what we could see, most participants had skied before or were regular skiers, demonstrating how this type of event attracts a specific segment of the community interested in this kind of sport.

Concerning interpersonal motivation, about two-thirds of the participants came with someone else with the remainder solo participants, showing the keen possibility of these events to establish social relationships with the community, reinforcing previous results [15] on successful online communities' user integration. Specifically, among participant conversations, some pointed out that they attended these events because they like being with people with similar interests, they like photography, meeting new people, and discovering a new place in a different way.

With regard to prestige/status motivations, most users expressed that they had used Instagram for some time and were active users. This shows how this social media can play an essential part in their social status. Most people said that they liked posting pictures to share their experiences with friends and relatives, but also to promote a specific region and to gain recognition among their followers through likes and comments (one participant stated: 'every like feels like a triumph!'). Moreover, all participants had public profiles on Instagram. In terms of leaders and hierarchy, usually most of the high 'influencer' users with thousands of followers were part of the organization, and wore an identification badge. Therefore, people went to them for information and, hence, gained a higher status because they proved themselves to be the most knowledgeable and involved in the events.

Faithfulness and sense of belonging to the online community: All participants the researcher talked to or heard in conversation expressed their willingness to attend similar meetup events. Some people said that participating in the event was a cheap way to visit places because of the discounts. In conversation, many participants expressed that the event was fun, that they were happy to have come and that they were enjoying the activities and the company of other users. Moreover, 
most participants were followers of the online community long before the events, many of them for more than two years, indicating that the existence of and belonging to the community occur before the events, and not the other way around (an online community forming around an event). Some people said that they identified with the community because they sympathized with its aim of promoting the discovery of Catalonia as a tourist destination, especially those with strong Catalan nationalist feelings. Others felt belonging to the community was something useful (to get to know new places, get discounts on activities, participate in competitions, etc.).

\section{Discussion}

From the previous theoretical and methodological framework as well as the empirical results on the online socialness of UGEs and the role of users, the originality of this research is the main characteristics of UGEs that are deduced (Figure 7). All these characteristics are interrelated as can be observed in Figure 7 and are explained as follows.

- Online community (Figure 7a): UGEs are interesting from a sociological point of view in the sense that they represent the translation of an online community into a reality, with offline impacts. Parallel to UGC, UGEs have the characteristic that people attending may or may not know one another but they have the potential to reach thousands of anonymous people in seconds, and have the capacity to go viral. This idea is reinforced by the significant percentage of Instagrammer participants (about one third) who came to the event alone but nevertheless as a member of the community, participants' strong interpersonal interactivity, and the crucial role of 'influencers' in brand dissemination. Moreover, both quantitative and qualitative results showed remarkable participant identification and faithfulness to these types of events in relation to the online community.

- UGC through social media (Figure 7b): The results showed that tourist UGEs are intrinsically related to the production of online UGC through social media and generate user engagement and interactivity through likes and comments. Social media are integrated within UGEs, to the extent that the event would not be possible, would lose all its significance or would not have happened without the specific social media, and would not have any significance either without people travelling physically to the site. The production of UGC in UGEs is a sine qua non condition, which indicates their high potential economic impact, as $\mathrm{C} 2 \mathrm{C}$ communication through UGC in online communities encourages sales and those who communicate most are those who purchase the most [31].

- Engagement and faithfulness (attraction capacity) (Figure 7f): Participant observation, indicated the perception of intrinsic motives of altruism of the community and social identification [32] which encourage users to engage with the online brand communities. The engagement with the events through social media is very high. As shown by the quantitative results and in spite of the limited size of the events, for the three together, in a very short period of time, about 300 Instagram users posted 1290 pictures, creating high engagement and online 'buzz', receiving about 200,000 likes and 16,000 comments in total, and potentially reaching more than three-quarter of a million people (followers). All that at little or no cost to destinations or tourism businesses-both in terms of time or money. Moreover, as quantitative results demonstrate, UGEs have a great capacity to attract people, and specifically Instagram UGEs can have a great deal of influence on and attraction for destinations, reinforcing the idea of Baksi [44] of their emotional bonding capacity, their ability to generate favourable images of a destination, and loyalty. In this respect, both quantitative and qualitative results showed remarkable faithfulness to these events and high repeat rate, with more than $20 \%$ of participants attending more than one event, and most confirming they would like to participate in similar future events with like-minded people with whom they felt identified.

- Tourist brand/image dissemination (Figure $7 \mathrm{~g}$ ): The promotional capacity of UGEs though online image/brand dissemination is extremely important. Because they originated from an online 
community, tourism UGEs may entail greater dissemination than regular events which use social media as part of their promotion. At UGEs, and especially Instagram meetups, UGC production is part of what people 'have' to and 'want' to do to participate in the event. Participants partly engaged in the photography competition to win a prize, but even if the prize had not existed, they would have participated for community recognition to gain a reputation/prestige [17] as an Instagrammer, and for the hedonism of posting experiential pictures. The core idea that to be a tourist is almost by necessity to be a photographer [43] is maintained or even incremented in UGE contexts bound to social media, especially Instagram, where it is even more compulsory to take and post pictures. Therefore, in UGEs, the reproduction of tourist images [43] and the closing of the hermeneutic circle $[68,69]$ through social media may be more intense, conscious, and purposeful, and contribute highly to promoting the destination or organization. Analysis shows that only a few selected photographs were posted on Instagram, probably the pictures users consider the 'best' or most 'original', offering an ideal picture of the place or the event. UGEs can also help to reinforce destination brand identity and image, as well as create and reinforce territorial links, related to tourism assets and offers.

- Influence and virality (Figure 7e): In relation to the latter, manifest content of online photographs has been found to influence the attitudes toward a destination and affect destination image formation [12]. If UGEs are successful and participants enjoy them and have fun, as the participant observation indicates, they will attach and transmit these sensations and feelings in relation to the destination, which will be reinforced by followers' comments. The positive link between taking photographs and tourist satisfaction and happiness [45] is thus supported by participant observation. These positive sensations can then be a source of inspiration for other travellers, increasing their desire to travel to the destination and participate in future events. Besides, these events organized by peers of the tourist and the information they transmit through eWOM bound to online communities (organic sources) can have a greater impact and provide much more effective and trustworthy marketing for the destination or organization than official sources, which are seen as interested traditional forms of advertising (overt induced sources) according to Gartner's [70] classification of tourist information sources. This idea of their high influence on users is reinforced by participant observation, which showed users' attachment and identification. Users perceived the motives behind the events as altruistic and disinterested, related to pride in their own country and promoting tourism, as well as socializing and having fun, which makes them more "permeable" to influence. In essence, UGEs have what makes UGC so influential and trustworthy: no perceived underlying self-interest or economic interest. Remarkably, along the lines of Hartmann [33], a few highly influential users were detected, who accounted for the majority of online disseminations, showing the great potential influence of certain posts and their capacity to go viral, reaching thousands of people in seconds.

- Event convocation and management by users (Figure 7d): Tourism UGEs, especially in the case of Instagram meetups, and unlike other spontaneous events created through social media, show the organizational capacity and empowerment of users as they are fully structured or semi-structured, organized and managed by users, and may entail formal registrations, membership, etc. The paper results show that ski resorts and business brands participated and mixed with participants as just another participant, informally and not as 'organizers', thus becoming more 'human' in the eyes of tourists. The sponsor's brand was clearly integrated in the event through the photography competition. The participant observation also showed in practice an event organization by peers and for peers, with meeting points, its publicity, participant identifications, group activities, etc.

- DMOs and tourism firms (Figure 7): Previous studies [2,33], although acknowledging people's new empowered and central role in events through UGC, always assumed that the company or the destination is a co-organizer or has an important degree of control over the event, or that the organization initiates social media integration in the event as part of a marketing strategy. Evaluation models, too, have usually been proposed from a management perspective, from the 
point of view or interest of the organization, even if in some cases they acknowledge the role of different stakeholders, including users [21]. Nonetheless, the empowered role of users in events, enabled by social media, can be much deeper, to the point of a complete paradigm shift in which users are the main initiators, creators, organizers and realizers of the event. Methods must be sought which respond to this new context and can contribute to broader evaluation models. As pointed out above, social media are not only useful tools to promote an event but also to organize collective action [4]. However, in spite of not taking the event's initiative, sponsors (firms or destinations) are convenient, and even necessary, for the creation of UGEs, as they make these events more attractive; provide logistical, economic, and/or promotional support and advantages for participants; and also result in promotional and economic benefits for organizations. Therefore, although the roles of companies and destinations in UGEs may change, they will likely continue to be very important for their development and collaboration in different ways.

- Paradigm shift: User initiative and empowerment (Figure 7c): The shift is that the event is at the initiative of the people, not the company or tourist destination, and it is taken in a user milieu. This reinforces the arguments which assess the empowerment of tourists and their increasing role as active agents $[9,10,71]$ generating online content and events in a solely user milieu, for which tourism organizations have difficulty accessing, much less control. In this context, companies and destinations acquire a facilitating role, which may be more or less proactive and may entail promotion, sponsorships, etc., but the initiative is not theirs. Therefore, the sentence 'We need to learn to let go' (Lafley, as cited in Hartmann [33]) may even acquire a deeper meaning or be used to go further, as the control of the event may be mostly or even entirely out of the hands of the destination or organization. The sentence could be transformed into: Sometimes, organizations need to let go and let customers take the reins!

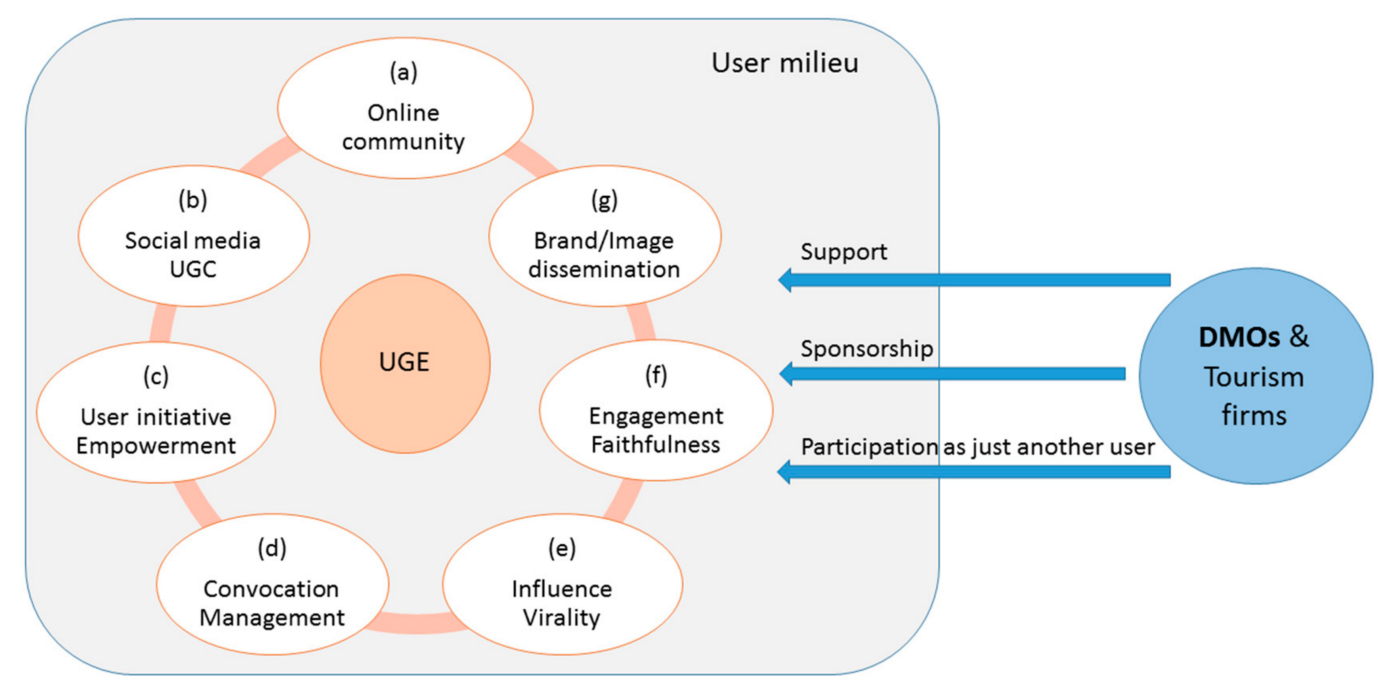

Figure 7. Main features of tourism user-generated social media events.

\section{Concluding Remarks}

User-generated events (UGEs) are a growing phenomenon and should be recognized and denominated as a differentiated type of event bound to social media, just as UGC are recognized as a differentiated type of content and research issue. UGEs are but an expression of the empowerment users have gained with the emergence of social media.

The main contribution of this research consists of defining tourism UGEs as events completely initiated and organized by users through social media for tourism purposes; UGEs have a specific 
structure and limits, are intrinsically bound to social media, and are the production of UGC and online communities.

This study's approach to the phenomenon of UGEs has demonstrated their great capacity for attraction and promotion through posting related UGC, which is potentially greater than for other types of events, with their potential to create user interactivity and the importance of 'influencers' in the phenomenon. It has also shown the unique characteristics of UGEs as a social phenomenon related to users' new empowered role as organizers and initiative takers, including high faithfulness and commitment of users, UGEs' ability to create emotional bonds with the brands, a strong sense of belonging to the community and motivations related to social prestige and interpersonal relationships. Photography-based UGEs organized through mobile social media, such as Instagram meetups, are especially interesting for tourism destinations and businesses because of the intrinsic link between photography and tourism, and due to sharing the 'best' or most 'original' pictures of a place with high doses of creativity, as well as for their specific capacity to transmit emotions and create engagement. Furthermore, social media users who post pictures online potentially spend more money and consume more than average at the destination.

\subsection{Theoretical and Methodological Contributions}

In event research, events have mostly been considered a product of organisational event management or planning (Brown et al., 2015) but an increasing stream of literature has emerged to include the new empowered role of customers in events as co-creators [2,33]. However, co-creation theories fall short in the comprehension of UGEs as users become full creators. Thus, this study contributes to theory in that it proposes a new user-centred focus/dimension or context to event studies in which users become the events' fully empowered creators/generators through social media and occupy a central position, which future works should consider. In this respect this research adds up to the "model of the evaluation process" of events [21] and asserts that event evaluation models should also include their online socialness and the role of users as event generators. The role of participants in the meetups is not only as mere consumers, but as producers of the experience and this empowerment could allow them to increase their knowledge and awareness of regional interests which is a benefit to the participatory and sustainable tourism development [72].

The originality of this study is that it has contributed to defining and characterizing UGEs in tourism, as a distinct phenomenon intrinsically bound to UGC and in measuring their online socialness through a mixed-methodology applied to UGC combined with qualitative methods, as participant observation. Although some previous event management and classification models [2] have introduced the role of social media in them, future theoretical models should also incorporate the role of users in generating events.

In this respect, this study has contributed to filling in the gap in the evaluation framework outlined by Brown et al. [21] by providing an innovative mixed-methodology model in the field of tourism and events, for assessing an event's online socialness which focuses on the evaluation of events in relation to social media and to an online community, which should be used within integral event evaluation models. Specifically, the proposed quantitative framework approach to store, analyse and compare events based on UML (Unified Modelling Language) enables the processing of UGEs in relation to UGC and to social media dynamics and can be used for the analysis and comparison of any type of event, both user and non-user-generated, and adapted to computerized analyses. Its combination with participant observation has been effective to provide a deeper socio-cultural understanding of UGEs, of their socialness and the empowered role of users and define their main characteristics, reinforcing the strength of mixed-methods to approach complex social phenomena.

\subsection{Managerial Implications}

Tourist businesses and destination marketers should be vigilant and aware of the existence and importance of UGEs, of their potentialities for brand promotion and consolidation, and the creation 
of engagement and relationships with users, at very little or no cost to them, in addition to their potential economic impact. Moreover, besides potential monetary gains, in this case, sponsors are wanted and cherished by the community (users), and are not promoted by third parties (the DMO, firms or organisations). Therefore, users will be more receptive to these sponsors and users' activity in social networks will be valuable for them. Hence, although these events are fully generated by users, DMOs and tourism organizations should try to play a role in them, by identifying the most interesting online communities in relation to their target publics, and then attempt to engage or collaborate with them. Through UGEs we can find the characteristics of a specific group or community with common interests, which is useful for targeting new publics and conducting segmented promotion. Specifically, Instagram meetups also show the importance of marketing a tourist business or destination through using mobile social media through specific campaigns and apps.

These types of events imply a paradigm shift in event management in that tourism organizations are no longer the primary initiators and controllers of an event, instead adopting a secondary role of accompaniment and backing, but they need to take advantage of the fact that these tourist events usually need sponsorship, facilitation or logistic and economic support. Event sponsorships are decisive because they make the events much more attractive and interesting by bringing benefits to the participants (in our case study, in the form of prizes and discounts on tickets to ski resorts), and they are likely to draw more people. Sponsors are needed in UGEs, especially in places where one must pay to access and provide advantages to companies as well as to destinations and users. This is a win-win relationship where users know that they can gain advantages from the destination or the company because the destination or company is also profiting from the UGE. Sponsors should also take advantage of the capacity to humanize the brands of these events and mix with users. In this respect, DMOs and tourism firms should adopt a largely "hands-off" approach or facilitating role when engaging in communication with users, as suggested in online brand community literature [31], and not try to control C2C communication.

Moreover, sports tourist activities in mountain environments are the origin of sustainability because of the economic and social impacts generated [73], in this sense, DMOs should take advantage of those impacts that can also alleviate tourist seasonality in ski resorts.

With UGEs, tourism destinations and companies need to learn to let go and let tourists take the reins, but they need to be on hand for support by providing attractive advantages for their development. If a destination or organization can attract tourism UGEs, it will have found a holy grail, because people will organize events for the organization, at minimal cost and promote it massively through UGC and eWOM.

\subsection{Limitations and Future Research}

This study analysed three meetups promoted by one specific Instagram community. The events took place in a specific geographical area: Catalonia. Therefore, the public attending the events is not representative of Instagram users in general, but of the members of a specific online community who are middle- aged and have medium-high economic power (the event was specially publicized as a family activity). Therefore, future studies should analyse UGEs held by other types of online communities and in other geographical areas. The scope of this study did not focus on the economic impact of the events, or the economic return of investment of sponsors. Thus, future studies should analyse other UGEs held through Instagram and other social media, and determine the economic and promotional impacts of these types of events in comparison to others. Future studies could also analyse participant satisfaction and feelings towards the events, as pointed out by Brown et al. [21], through the content analysis of the online posts and sentiment analysis techniques.

Acknowledgments: This work was supported by the Spanish Ministry of Economy and Competitiveness [Grant ID.: MOVETUR CSO2014-51785-R]. Special thanks to Neus Mangues Tarroja for her support in gathering field data. The authors state that they have not received funds to cover the costs of publishing in open access. 
Author Contributions: All authors collaborated equally. Estela Marine wrote the paper. Eva Martin and Natalia Daries made the proposals, modifications, extensions and other contributions that they considered appropriate.

Conflicts of Interest: The authors declare no conflict of interest.

\section{References}

1. Van Dijck, J.; Poell, T. Understanding social media logic. Media Commun. 2013, 1, 2-14. [CrossRef]

2. Zanger, C. Ein überblick zu Events im Zeitalter von Social Media; An overview of events in the age of Social Media; Springer: Berlin, Germany, 2014. [CrossRef]

3. Kaplan, A.M.; Haenlein, M. Users of the world, unite! The challenges and opportunities of Social Media. Bus. Horiz. 2010, 53, 59-68. [CrossRef]

4. Segerberg, A.; Bennett, W.L. Social Media and the organization of collective action: Using Twitter to explore the ecologies of two climate change protests. Commun. Rev. 2011, 14, 197-215. [CrossRef]

5. Shirky, C. The political power of social media. For. Aff. 2011, 90, $28-41$.

6. Lee, W.; Tyrrell, T.J. Arizona meeting planners' use of social networking media. In Social Media in Travel, Tourism and Hospitality: Theory, Practice and Cases; Sigala, M., Christou, E., Gretzel, U., Eds.; Ashgate Publishing: Surrey, UK, 2012; pp. 121-132.

7. Hays, S.; Page, S.J.; Buhalis, D. Social media as a destination marketing tool: Its use by national tourism organisations. Curr. Issues Tour. 2013, 16, 211-239. [CrossRef]

8. Xiang, Z.; Gretzel, U. Role of social media in online travel information search. Tour. Manag. 2010, 31, $179-188$. [CrossRef]

9. Hvass, K.A.; Munar, A.M. The takeoff of social media in tourism. J. Vacat. Mark. 2012, 18, 93-103. [CrossRef]

10. Sigala, M.; Christou, E.; Gretzel, U. Social Media in Travel, Tourism and Hospitality: Theory, Practice and Cases; Sigala, M., Christou, E., Gretzel, U., Eds.; Ashgate Publishing: Surrey, UK, 2012.

11. Marine-Roig, E. Measuring destination image through travel reviews in search engines. Sustainability 2017, 9, 1425. [CrossRef]

12. Kim, H.; Stepchenkova, S. Effect of tourist photographs on attitudes towards destination: Manifest and latent content. Tour. Manag. 2015, 49, 29-41. [CrossRef]

13. Marine-Roig, E.; Anton Clavé, S. Tourism analytics with massive user-generated content: A case study of Barcelona. J. Destin. Mark. Manag. 2015, 4, 162-172. [CrossRef]

14. Lu, W.; Stepchenkova, S. User-generated content as a research mode in tourism and hospitality applications: Topics, methods, and software. J. Hosp. Mark. Manag. 2015, 24, 119-154. [CrossRef]

15. Casaló, L.V.; Flavián, C.; Guinalíu, M. New members' integration: Key factor of success in online travel communities. J. Bus. Res. 2013, 66, 706-710. [CrossRef]

16. Qu, H.; Lee, H. Travelers' social identification and membership behaviors in online travel community. Tour. Manag. 2011, 32, 1262-1270. [CrossRef]

17. Kunz, W.; Seshadri, S. From virtual travelers to real friends: Relationship-building insights from an online travel community. J. Bus. Res. 2015, 68, 1822-1828. [CrossRef]

18. Hudson, S.; Roth, M.S.; Madden, T.J.; Hudson, R. The effects of social media on emotions, brand relationship quality, and word of mouth: An empirical study of music festival attendees. Tour. Manag. 2015, 47, 68-76. [CrossRef]

19. Inversini, A.; Williams, N.L. Social media and events. In Events Management: An International Approach; Ferdinand, N., Kitchen, P.J., Eds.; SAGE Publications: London, UK, 2016; pp. 271-287.

20. Montanari, F.; Scapolan, A.; Codeluppi, E. Identity and social media in an art festival. In Tourism Social Media: Transformations in Identity, Community and Culture; Munar, A.M., Gyimóthy, S., Cai, L., Eds.; Emerald Group Publishing Limited: Bingley, UK, 2013; pp. 207-225.

21. Brown, S.; Getz, D.; Pettersson, R.; Wallstam, M. Event evaluation: Definitions, concepts and a state of the art review. Int. J. Event Festiv. Manag. 2015, 6, 135-157. [CrossRef]

22. Mair, J.; Whitford, M. An exploration of events research: Event topics, themes and emerging trends. Int. J. Event Festiv. Manag. 2013, 4, 6-30. [CrossRef]

23. Chandler, D.; Munday, R. A Dictionary of Social Media; Oxford University Press: Oxford, UK, 2016.

24. Getz, D.; Page, S.J. Progress and prospects for event tourism research. Tour. Manag. 2016, 52, 593-631. [CrossRef] 
25. Getz, D. Event tourism: Definition, evolution, and research. Tour. Manag. 2008, 29, 403-428. [CrossRef]

26. Pechlaner, H.; Bò, G.D.; Pichler, S. Differences in perceived destination image and event satisfaction among cultural visitors: The case of the European Biennial of Contemporary Art "Manifesta 7". Event Manag. 2013, 17, 123-133. [CrossRef]

27. Kim, J.; Kang, J.H.; Kim, Y.-K. Impact of mega sport events on destination image and country image. Sport Mark. Q. 2014, 23, 161-175.

28. Lai, K.; Li, Y. Image impacts of planned special events: Literature review and research agenda. Event Manag. 2014, 18, 111-126. [CrossRef]

29. Bolan, P. A perspective on the near future: Mobilizing events and social media. In The Future of Events and Festivals; Yeoman, I., Robertson, R., McMahon-Beattie, U., Smith, K.A., Backer, E., Eds.; Routledge: Oxford, UK, 2014; pp. 199-209.

30. Litvin, S.W.; Goldsmith, R.E.; Pan, B. A retrospective view of electronic word of mouth in hospitality and tourism management. Int. J. Contemp. Hosp. Manag. 2017, 1-34, in press. [CrossRef]

31. Adjei, M.T.; Noble, S.M.; Noble, C.H. The influence of $\mathrm{C} 2 \mathrm{C}$ communications in online brand communities on customer purchase behavior. J. Acad. Mark. Sci. 2010, 38, 634-653. [CrossRef]

32. Lee, D.; Kim, H.S.; Kim, J.K. The impact of online brand community type on consumer's community engagement behaviors: Consumer-created vs. marketer-created online brand community in online social-networking web sites. Cyberpsychol. Behav. Soc. Netw. 2011, 14, 59-63. [CrossRef] [PubMed]

33. Hartmann, D. User generated events. In Erfolg mit Nachhaltigen Eventkonzepten; Zanger, C., Ed.; Gabler Verlag: Heidelberg, Germany, 2012; pp. 23-36. [CrossRef]

34. Wood, E. The Value of Connection: A Review of Social Media Trends; Meeting Professionals International (MPI): Dallas, TX, USA, 2013.

35. Wittel, A. Toward a network sociality. Theory Cult. Soc. 2001, 18, 51-76. [CrossRef]

36. Couldry, N.; van Dijck, J. Researching social media as if the social mattered. Soc. Media Soc. 2015, 1, 1-7. [CrossRef]

37. Cole, S. Information and empowerment: The keys to achieving sustainable tourism. J. Sustain. Tour. 2006, 14, 629-644. [CrossRef]

38. Roy, S.D.; Zeng, W. Media on the Web. In Social Multimedia Signals; Springer International Publishing: Cham, Switzerland, 2015; pp. 9-18. [CrossRef]

39. Lo, I.S.; McKercher, B.; Lo, A.; Cheung, C.; Law, R. Tourism and online photography. Tour. Manag. 2011, 32, 725-731. [CrossRef]

40. Nusair, K.; Erdem, M.; Okumus, F.; Bilgihan, A. Users' attitudes toward online social networks in travel. In Social Media in Travel, Tourism and Hospitality; Sigala, M., Christou, E., Gretzel, U., Eds.; Ashgate: Surrey, UK, 2012; pp. 207-224.

41. Lister, M. Too many photographs? Photography as user generated content. AdComun. Rev. Cient. Estrateg. Tend. Innov. Comun. 2011, 2, 25-41. [CrossRef]

42. Abbott, W.; Donaghey, J.; Hare, J.; Hopkins, P.J. An Instagram is worth a thousand words: An industry panel and audience Q\&A. Libr. Hi Tech News 2013, 30, 1-6. [CrossRef]

43. Markwell, K.W. Dimensions of photography in a nature-based tour. Ann. Tour. Res. 1997, 24, 131-155. [CrossRef]

44. Baksi, A.K. Destination bonding: Hybrid cognition using Instagram. Manag. Sci. Lett. 2016, 6, 31-46. [CrossRef]

45. Gillet, S.; Schmitz, P.; Mitas, O. The snap-happy tourist: The effects of photographing behavior on tourists' happiness. J. Hosp. Tour. Res. 2016, 40, 37-57. [CrossRef]

46. Bynum Boley, B.; Magnini, V.P.; Tuten, T.L. Social media picture posting and souvenir purchasing behavior: Some initial findings. Tour. Manag. 2013, 37, 27-30. [CrossRef]

47. Walle, A.H. Quantitative versus qualitative tourism research. Ann. Tour. Res. 1997, 24, 524-536. [CrossRef]

48. Kaushik, A. Best social media metrics: Conversation, amplification, applause, economic value. Digit. Mark. Anal. Blog 2011, 1-11. Available online: http://www.kaushik.net/avinash/best-social-media-metricsconversation-amplification-applause-economic-value/ (accessed on 4 April 2017).

49. Zarrella, D. The Social Media Marketing Book; O'Reilly Media: Sebastopol, CA, USA, 2009. 
50. Pan, B.; You, Y. Conceptualizing and measuring online behavior through social media metrics. In Analytics in Smart Tourism Design: Concepts and Methods; Xiang, Z., Fesenmaier, D.R., Eds.; Springer: Heidelberg, Germany, 2017; pp. 203-211. [CrossRef]

51. Agostino, D.; Sidorova, Y. A performance measurement system to quantify the contribution of social media: New requirements for metrics and methods. Meas. Bus. Excell. 2016, 20, 38-51. [CrossRef]

52. Peters, K.; Chen, Y.; Kaplan, A.M.; Ognibeni, B.; Pauwels, K. Social media metrics-A framework and guidelines for managing social media. J. Interact. Mark. 2013, 27, 281-298. [CrossRef]

53. Huertas, A.; Marine-Roig, E. Destination brand communication through the social media: What contents trigger most reactions of users? In Information and Communication Technologies in Tourism; Tussyadiah, I., Inversini, A., Eds.; Springer: Cham, Switzerland, 2015; pp. 295-308. [CrossRef]

54. Huertas, A.; Marine-Roig, E. User reactions to destination brand contents in social media. Inf. Technol. Tour. 2016, 15, 291-315. [CrossRef]

55. Carah, N.; Shaul, M. Brands and Instagram: Point, tap, swipe, glance. Mob. Media Commun. 2016, 4, 69-84. [CrossRef]

56. Booch, G.; Rumbaugh, J.; Jacobson, I. Unified Modeling Language User Guide; Addison-Wesley: Boston, MA, USA, 2005.

57. Hopken, W. Reference model of an electronic tourism market. In Information and Communication Technologies in Tourism; Fesenmaier, D.R., Klein, S., Buhalis, D., Eds.; Springer: Vienna, Austria, 2000; pp. 265-274. [CrossRef]

58. Mackellar, J. Participant observation at events: Theory, practice and potential. Int. J. Event Festiv. 2013, 4, 56-65. [CrossRef]

59. Bowen, D. Research through participant observation in tourism: A creative solution to the measurement of consumer satisfaction/dissatisfaction (CS/D) among tourists. J. Travel Res. 2002, 41, 4-14. [CrossRef]

60. Konijn, E.; Slumer, N.; Mitas, O. Click to share: Patterns in tourist photography and sharing. Int. J. Tour. Res. 2016, 18, 525-535. [CrossRef]

61. Jorgensen, D.L. Participant Observation: A Methodology for Human Studies; Sage Publications: London, UK, 1989.

62. DeWalt, K.M.; DeWalt, B.R. Participant Observation: A Guide for Fieldworkers, 2nd ed.; AltaMira Press: Plymouth, UK, 2010.

63. Getz, D. Special events: Defining the product. Tour. Manag. 1989, 10, 125-137. [CrossRef]

64. Aslam, S. Instagram by the Numbers: Stats, Demographics \& Fun Facts. 2017. Available online: https: / /www.omnicoreagency.com/instagram-statistics/ (accessed on 4 April 2017).

65. Hu, Y.; Manikonda, L.; Kambhampati, S. What we Instagram: A first analysis of Instagram photo content and user types. In Proceedings of the Eighth International AAAI Conference on Weblogs and Social Media (ICWSM 2014), Ann Arbor, MI, USA, 1-4 June 2014; pp. 595-598.

66. Ferrara, E.; Interdonato, R.; Tagarelli, A. Online popularity and topical interests through the lens of Instagram. In ACM Hypertext and Social Media; ACM Digital Library: New York, NY, USA, 2014; pp. 24-34. [CrossRef]

67. Instagram. Instagram Community. 2017. Available online: https://community.instagram.com/ (accessed on 4 April 2017).

68. Caton, K.; Almeida Santos, C. Closing the hermeneutic circle? Photographic encounters with the other. Ann. Tour. Res. 2008, 35, 7-26. [CrossRef]

69. Marine-Roig, E. Identity and authenticity in destination image construction. Anatolia Int. J. Tour. Hosp. Res. 2015, 26, 574-587. [CrossRef]

70. Gartner, W.C. Image formation process. J. Travel Tour. Mark. 1993, 2, 191-215. [CrossRef]

71. Munar, A.M. Tourist-created content: Rethinking destination branding. Int. J. Cult. Tour. Hosp. Res. 2011, 5, 291-305. [CrossRef] 
72. Timothy, D.J.; Tosun, C. Arguments for community participation in the tourism development process. J. Tour. Stud. 2003, 14, 2-15.

73. Duglio, S.; Beltramo, R. Estimating the economic impacts of a small-scale sport tourism event: The case of the Italo-Swiss mountain trail CollonTrek. Sustainability 2017, 9, 343. [CrossRef] 